\title{
GOMMENTS
}

\section{REASON AND THE RULES: \\ PERSONAL KNOWLEDGE AND COCONSPIRATOR HEARSAY}

\section{Camille Paglia Francis $\dagger$}

In United States $v$. Ammar, ${ }^{1}$ the United States Court of Appeals for the Third Circuit held that the personal knowledge foundation requirement of Federal Rule of Evidence $602^{2}$ did not apply to coconspirator statements admissible under Rule $801(\mathrm{~d})(2)(\mathrm{E}) .^{3}$ The facts of the case are by no means unusual, ${ }^{4}$ and it is likely that a conviction would have resulted whether or not the coconspirator statements at issue had been admitted at trial. ${ }^{5}$ What is unusual about this case and its progeny is that they seem to have escaped notice almost entirely-even by the courts that decided them-despite the fact that this evidentiary ruling points to serious inconsistencies within the Federal Rules of Evidence that go to the very heart of the federal coconspirator hearsay exception. ${ }^{6}$

$\dagger$ A.B. 1983, Bryn Mawr College; M.G.A. 1986, J.D. Candidate 1988, University of Pennsylvania. The author wrote this piece while a student at the University of Pennsylvania Law School.

1714 F.2d 238 (3d Cir.), cert. denied, 464 U.S. 936 (1983).

2 The Rule states, in relevant part, "A witness may not testify to a matter unless evidence is introduced sufficient to support a finding that he has personal knowledge of the matter." FED. R. Evid. 602.

${ }^{3}$ See Ammar, 714 F.2d at 254. Federal Rule of Evidence 801(d)(2)(E) states: "A statement is not hearsay if . . . [it] is offered against a party . . . during the course and in furtherance of the conspiracy."

4 See Ammar, 714 F.2d at 243-45. The case involved the importation of heroin from Lebanon. See infra notes 15-17 and accompanying text for a full discussion of the facts.

s See Ammar, 714 F.2d at 257 n.16. The court found the coconspirator statements at issue to be corroborated by other evidence.

"Strictly speaking, the "coconspirator hearsay exception" of Federal Rule of Evidence $801(d)(2)(E)$ is not an "exception" at all; rather, it is characterized as "not hearsay" under the Rules. The contrary view holds that admissions, including those imputed to a party because they were made by a coconspirator, are exceptions to the hearsay rule. See, e.g., MODEL CODE OF Evidence Rule 508(b) (1947) (treating agents' and coconspirators' "vicarious admissions" as exceptions to the hearsay rule); 
The Ammar court relied heavily on an Eighth Circuit case, Mahlandt $v$. Wild Canid Survival $\mathcal{E}^{2}$ Research Center, Inc., ${ }^{7}$ in which the court stated that the personal knowledge requirement of Rule 602 was not applicable to Rule 801 (d)(2)(D), relating to statements made by agents or servants. ${ }^{8}$ Mahlandt and Ammar drew their primary support from a passage in the Advisory Committee's Note to Rule 801(d)(2), which states:

No guarantee of trustworthiness is required in the case of an admission. The freedom which admissions have enjoyed from technical demands of searching for an assurance of trustworthiness in some against-interest circumstances, and from the restrictive influences of the opinion rule and the rule requiring firsthand knowledge, when taken with the apparently prevalent satisfaction with the results, calls for generous treatment of this avenue to admissibility. ${ }^{\circ}$

While several courts have followed Mahlandt in rejecting a personal knowledge requirement in the Rule 801 (d)(2)(D) agency context, ${ }^{10}$ few have followed the Third Circuit's lead in exempting coconspirator statements from the ambit of Rule $602 .{ }^{11}$ Courts have begun only recently to address the issue of reconciling Rule 602 and the Advisory Committee's Note to Rule 801 (d)(2), however, and many will almost certainly have to take a position in the near future. In the criminal conspiracy context, in particular, the use at trial of coconspirator "admissions" not based on the declarant's personal knowledge is problematic. ${ }^{12}$

With this in mind, two major areas of concern can be identified.

UnIF. R. Evid. 63(9)(a) (requiring that the statement be admissible if made by the declarant at trial) and 19 (requiring wiinesses to have personal knowledge); Levie, Hearsay and Conspiracy, 52 Mich. L. Rev. 1159, 1163 (1954) ("Once it was believed that admissions were not hearsay. Nobody today would adopt so naive a view." (footnote omitted)).

7588 F.2d 626 (8th Cir. 1978).

See id. at 630-31.

9 FED. R. Evid. 801(d)(2) advisory committee's note.

${ }^{10}$ See, e.g., Union Mut. Life Ins. Co. v. Chrysler Corp., 793 F.2d 1, 8-9 (1st Cir. 1986); MCI Communications Corp. v. AT\&T, 708 F.2d 1081, 1143 (7th Cir. 1983), cert. denied, 464 U.S. 891 (1984); In re A.H. Robins Co., 575 F. Supp. 718, 723-25 (D. Kan. 1983). The Third Circuit is also presumably in this group. See Ammar, 714 F.2d at 254. The Second Circuit expressly declined to decide the issue in United States v. Southland Corp., 760 F.2d 1366, 1376 n.4 (2d Cir.), cert. denied, 106 S. Ct. 82 (1985).

${ }^{13}$ See, e.g., United States v. McLernon, 746 F.2d 1098, 1106 (6th Cir. 1984) (adopting without comment the Ammar rule); United States v. Badalamenti, 626 F. Supp. 658, 662 (S.D.N.Y. 1986) (same).

12 See infra notes 55-77 and accompanying text. 
The first has to do with the reliability problems inherent in all hearsay, but which are particularly acute with coconspirator hearsay, ${ }^{13}$ and which are rooted in the rationale behind the coconspirator exception as it evolved in Anglo-American jurisprudence and was codified in the Federal Rules. ${ }^{14}$ A personal knowledge requirement would add a much-needed guarantee of trustworthiness to coconspirator hearsay that is admitted as substantive evidence. A second objection to the admission of coconspirator statements not based on personal knowledge is that the use of this type of hearsay evidence at trial leads to two anomalies: first, the admission of an out-of-court statement where the declarant, if present at trial, would not be permitted to testify to its content because of a lack of personal knowledge of the subject matter; second, the admission of problematic hearsay within hearsay.

This Comment argues that the personal knowledge foundation requirement of Rule 602 should apply to coconspirator statements admissible under Rule $801(\mathrm{~d})(2)(\mathrm{E})$. Because coconspirator declarations stand on quite a different footing from other "admissions" vis-à-vis the hearsay rule, they require greater assurances of trustworthiness. Part I of this Comment examines the cases that have thus far addressed this issue. Part II discusses, in turn, the concerns outlined above. Part III concludes that a personal knowledge requirement for coconspirator statements and a rejection of the Advisory Committee's unprincipled codification of the common law view of coconspirator "admissions" are necessary to ensure the reliability of such evidence.

\section{The Cases}

The facts of United States $v$. Ammar ${ }^{15}$ are relatively straightforward and of a pattern familiar to students of evidence: Ghassan Ammar, his wife Judith Ammar, Marshall Stillman, and Roger $\mathrm{McF}$ ayden were convicted in federal court on multiple counts involving a conspiracy to import and distribute heroin from Lebanon. Four coconspirators testified against the defendants at trial. ${ }^{16}$ On appeal, defendant Marshall Stillman objected to the admission of out-of-court statements of certain of his coconspirators because those statements

13 Notwithstanding the Federal Rules' classification of coconspirator statements as "not hearsay," see supra note 6, these out-of-court declarations offered for the truth of the matter asserted are commonly referred to as "hearsay," as will be the case throughout this Comment.

14 See infra notes $48-77$ and accompanying text.

15714 F.2d 238 (3d Cir.), cert. denied, 464 U.S. 936 (1983).

16 See id. at 243-45. 
were not shown to be based on the declarants' personal knowledge. ${ }^{17}$ The Third Circuit did not reject Stillman's contention on the grounds of harmless error:;8 rather, the court held the statements admissible despite the declarants' lack of personal knowledge, stating:

[I]t is clear from the Advisory Committee Notes that the drafters intended that the personal knowledge foundation requirement of Rule 602 should apply to hearsay statements admissible as exceptions under Rules 803 and 804 but not to admissions (including coconspirator statements) admissible under Rule 801 (d)(2). ${ }^{19}$

The court cited as an authority for this assertion Mahlandt $v$. Wild Canid Survival $\&$ Research Center,. Inc. ${ }^{20}$ Mahlandt involved an appeal from a jury verdict in favor of defendant Wild Canid Survival \& Research Center, Inc. in a suit arising from an alleged attack by a tame wolf named Sophie on a boy named Daniel Mahlandt. ${ }^{21}$ An employee of the Center, Kenneth Poos, did not see the attack ${ }^{22}$ but told his superiors that Sophie had bitten a child. The trial judge refused to admit this statement under the newly-enacted Federal Rules of Evidence because Mr. Poos had no personal knowledge of the facts. ${ }^{23}$ The Eighth Circuit reversed, holding that the statement was admissible against Wild Canid as an agent's statement under Rule 801(d)(2)(D) and that no personal knowledge requirement was to be read into the Rule, even though the trial judge "clearly found that the evidence was not reliable." ${ }^{24}$ The court referred to the Advisory Committee's comment calling for "generous treatment" in freeing admissions from the "technical demands of searching for an assurance of trustworthiness."25 The court, then, did not consider reliability to be important in the case of an admission of a party opponent, even though the statement was

17 See id. at $250,254,257$. The opinion of the court is unclear concerning which of the several coconspirator statements involved were allegedly not based on firsthand knowledge of the declarants.

${ }^{18}$ In light of the other evidence in the case, it almost certainly could have done so. See id. at 257; supra note 5 .

19 Ammar, 714 F.2d at 254.

20588 F.2d 626 (8th Cir. 1978).

21 See id. at 628-29. For a more detailed account of the facts of this case than is provided by the Eighth Circuit's opinion, see Bein, Parties' Admissions, Agents' Admissions: Hearsay Wolves in Sheep's Clothing, 12 HoFstra L. REv. 393, 393-401 (1984).

${ }_{22}$ There was reason to doubt that Sophie was the attacker. See Mahlandt, 588 F.2d at 629 ; Bein, supra note 21 , at $396-98$ \& n.25

${ }^{23}$ See Mahlandt, 588 F.2d at 629.

24 See id. at 630-31.

${ }^{25}$ Id. at 631 (quoting Advisory Committee's Note to Rule 801(d)(2)). 
that of an agent and not the party itself.

Over the objections of commentators, ${ }^{26}$ the post-Mahlandt cases have followed the Eighth Circuit's rejection of a personal knowledge requirement in the context of agents' statements. In MCI Communications Corp. v. $A T \mathcal{E}^{\mathrm{T} T}{ }^{27}$ defendant AT\&T objected to the admission of portions of an internal report prepared by its employees on the grounds that the document was based on hearsay and opinion. The Seventh Circuit found that the trial court had not abused its discretion in admitting the report because the employees were agents of AT\&T, making the document an admission by the corporation under Rule 801 (d)(2)(D). ${ }^{28}$ Similarly, in Union Mutual Life Insurance Co. v. Chrysler Corp. ${ }^{29}$ a letter written to Chrysler by an employee of Computer Systems of America (CSA), a company that leased computer equipment to Chrysler, was found by the First Circuit to be admissible against CSA under Rule 801(d)(2)(D) even though the letter was not based on the writer's personal knowledge ${ }^{30}$ And in In re A.H. Robins Co., ${ }^{31}$ which involved the Dalkon Shield products liability litigation, a federal court admitted the depositions of six Robins employees as agents' statements under Rule 801(d)(2)(D), noting that "there is . . no need to demonstrate that the declarant . . . has firsthand knowledge of the facts he is relating. The continuing employment relationship and the connection between the statement and the Dalkon Shield project are basically all that is necessary."32 Both Union Mutual and Robins relied heavily on the Advisory Committee's Note to Rule 801(d)(2). ${ }^{33}$

Fewer courts have followed the Third Circuit's lead in extending Mahlandt to coconspirator declarations; in fact only two have done so thus far. In United States v. McLernon, ${ }^{34}$ a drug conspiracy case, defendants Richard Scott McLernon and Sherri Louise Farrell objected to the admission of prearrest statements of a coconspirator, Marco Antonio Valdez-Gota, concerning McLernon and Farrell's involvement

2B See, e.g., 4 J. WEINSTEIN \& M. BERGER, WEINSTEIN's Evidence If $801(\mathrm{~d})(2)(\mathrm{C})[01]$, at 801-216 to -218 (1985) (arguing that the rationale for admitting party admissions becomes suspect when applied to agents' statements not based on personal knowledge, and runs contrary to the philosophy of Rules 403 and 805); Bein, supra note 21, at 451-52 (arguing that Rules 801 (d)(2)(C) and (D) should be redrafted as exceptions to the hearsay rule and, accordingly, that personal knowledge of the declarant should be required to ensure reliability).

27708 F.2d 1081 (7th Cir. 1983), cert. denied, 464 U.S. 891 (1984).

${ }^{28}$ See id. at 1143.

29793 F.2d 1 (1st Cir. 1986).

so See id. at 8-9.

31575 F. Supp. 718 (D. Kan. 1983).

32 Id. at 724.

${ }^{33}$ See Union Mutual, 793 F.2d at 8; Robins, 575 F. Supp. at 723-24.

34 746 F.2d 1098 (6th Cir. 1984). 
as couriers for Valdez's cocaine operation. ${ }^{35}$ Without comment, the Sixth Circuit cited Ammar and stated that with regard to coconspirators' statements, " $[t]$ he requirement that the declarant have personal knowledge of his statements . . . is waived."36

In United States v. Badalamenti, ${ }^{37}$ a district court in New York, perhaps not unmindful of the Second Circuit's comment that a "reconciliation of Rules 801 (d)(2) and 602 should await a case where this is essential,"s8 ruled that "[p]ersonal knowledge of the declarant is not required where the basis of admissibility is the defendant co-conspirator's authorization (under agency theory) to make the statements-especially where, as here, the statement is within the knowledge of the 'authorizing' defendants."38 Badalamenti, another drug conspiracy case, involved a statement made at a Sicilian farmhouse by one Carlo Castronovo to Salvatore Contorno, a government witness. ${ }^{40}$ Carlo told Contorno, allegedly in order to induce him to participate in narcotics transactions, that Carlo's cousin and coconspirator in America, defendant Frank ("Ciccio") Castronovo, used pizza parlors as a front for drug dealing. ${ }^{41}$ It is unclear, and the court does not explain, why the fact that this information was within the knowledge of the defendant Frank Castronovo should argue for its admissibility against him when he himself neither made nor explicitly authorized the statement. ${ }^{42}$

\section{Problems Inherent in the Admission of Coconspirator Statements Not Based on the Declarant's Personal. KNOWLEDGE}

\section{A. Reliability and the Evolution of the Coconspirator Hearsay Exception}

At common law, party admissions were admissible against the de-

ss See id. at 1103-04.

${ }^{36}$ McLernon, 746 F.2d at 1106.

${ }^{37} 626$ F. Supp. 658 (S.D.N.Y. 1986).

s8 United States v. Southland Corp., 760 F.2d 1366, 1376 n.4 (2d Cir.), cert. denied, 106 S. Ct. 82 (1985). Had the Southland court decided whether Rule 801 (d)(2) requires that the declarant have firsthand knowledge, it would have considered Rule $801(d)(2)(D)$ and agency, rather than Rule $801(d)(2)(E)$ and coconspiracy. The issues, however, are nearly identical.

39 Badalamenti, 626 F. Supp. at 662.

4 See id. at 662-63.

11 See id. at 662.

42 See id. The court seems to be carrying the agency theory of conspiracy to an extreme by characterizing what might just as easily have been Carlo's "puffing" about his American cousin as "authorized" statements. 
clarant regardless of whether the declarant had firsthand knowledge of the facts, ${ }^{43}$ was stating an opinion, or was simply relating the opinion of another. ${ }^{44}$ The reason for this rule was said to be that the standard hearsay objection-lack of opportunity to cross-examine the witness-was not here present, because the declarant "certainly . . . cannot complain of [a] lack of opportunity to cross-examine himself. . . . [A]s opponent [he] has the full opportunity to put himself on the stand and explain his former assertion."45 As commentators have observed over the years, however, this argument loses its force when the declarant is not a party to the litigation, but merely a party's representative. ${ }^{48}$ The basis for the agency exception is especially weak in the absence of specific authorization from the party. ${ }^{47}$

The coconspirator hearsay exception evolved along slightly different lines. It first appeared in its present form in the eighteenth century English treason trials of those who "taught and advocated" the death of the King by sympathizing with the French Revolution. ${ }^{48}$ The doctrine that admits a coconspirator's declarations against her fellows developed

4s See C. McCormick, McCormick on Evidence $\S 263$, at 778-79 (3d ed. 1984); 4 J. WigmoRe, Wigmore ON EvidenCE $\S 1053$, at 16-18 (Chadbourn rev. 1972).

14 See C. MCCoRmICR, supra note $43, \S 264$, at 779; 4 J. WIGMORE, supra note $43, \S 1053$, at $19-21$.

is $4 \mathrm{~J}$. WIGMORE, supra note $43, \S 1048$, at $4-5$.

18 See, e.g., 4 J. WeINSTEIN \& M. BerGer, supra note 26; Bein, supra note 21, at 428 (stating that "the limited rationale that justifies treating both reliable and unreliable party admissions identically for purposes of admissibility does not logically extend to statements made by nonparty declarants." (footnotes omitted)); Falknor, Vicarious Admissions and the Uniform Rules, 14 VAND. L. REv. 855, 860 (1961) (doctrine admitting party utterances whether or not based on personal knowledge is difficult to justify, especially where the admission was made by an employee and not the party herself); Morgan, The Rationale of Vicarious Admissions, 42 HARV. L. REv. 461, 463 \& n.4 (1929) (if vicarious admissions are to be received in evidence, it should be because the statements are trustworthy, as when they are within the declarant's personal knowledge, and not because of the existence of a master-servant relationship).

47 The Federal Rules of Evidence nevertheless expanded the law of agency. At common law, agents' statements were admissible against the principal only if explicitly authorized by the latter. See $4 \mathrm{~J}$. WeINSTEIN \& M. BERGER, supra note 26, II 801(d)(2)(D)[01], at 801-218 to -219; see also DeFrancesco v. Western Pa. Water Co., $329 \mathrm{~Pa}$. Super. 508, 521, 478 A.2d 1295, 1301-02 (1984) (stating that the rule in Pennsylvania is the "traditional vicarious admission rule requiring proof of agency plus authority . . . ."). Judge Weinstein has argued that agents' statements should be admitted if made in the course of employment and if related to the employment, but only if the statement is based on personal knowledge. See $4 \mathrm{~J}$. WEInstein \& M. Berger, supra note 26, I 801(d)(2)(D)[01], at 801-221 to -227; see also Carswell v. Southeastern Pa. Transp. Auth., 259 Pa. Super. 167, 181-82, 393 A.2d 770, 777 (1978) (opinion of Spaeth, P.J.) (arguing that unauthorized employee statements should be admitted only if based on personal knowledge or if some other indicia of reliability is present).

48 See Levie, supra note 6, at 1162; Mueller, The Federal Coconspirator Exception: Action, Assertion, and Hearsay, 12 Hofstra L. REv. 323, 325-26 (1984). 
as an extension of the substantive law of agency. ${ }^{48}$ In 1827 , the United States Supreme Court formulated the doctrine for American courts in the leading case of United States $v$. Gooding: ${ }^{.0}$

[I]n cases of conspiracy and riot, when once the conspiracy or combination is established, the act of one conspirator, in the prosecution of the enterprise, is considered the act of all, and is evidence against all. Each is deemed to consent to, or command, what is done by any other in furtherance of the common object. ${ }^{51}$

Federal Rule of Evidence 801(d)(2)(E) is essentially a codification of the common law rule. ${ }^{52}$ As the framers of the Rules themselves recognized, however, "the agency theory of conspiracy is at best a fiction." 53 That it is difficult to rationalize imputing to a party statements made by its agent or representative has been noted; that this difficulty is compounded in the case of a coconspirator's declarations should be obvious. At least a colorable argument can be made for imputing to an employer a statement made by an employee while acting within the scope of her duties. There may, in some cases, be a community of interest between the two-at the very least, the employee may often avoid making untrue and damaging statements about her employer because she wishes to retain her job. ${ }^{54}$

No such argument can be made for the admission of coconspirator hearsay, however, and it is here that the problem of reliability becomes particularly acute. ${ }^{\text {ss }}$ Unlike the statements of a party, who "can

40 See Levie, supra note 6, at 1163; Mueller, supra note 48, at 331-32; see also C. MCCoRMICK, supra note $43, \S 267$, at 792 n.36 ("If A and B are engaged in a conspiracy the acts and declarations of $B$ occurring while the conspiracy is actually in progress and in furtherance of the design are provable against A, because they are acts for which he is criminally or civilly responsible, as a matter of substantive law.").

so 25 U.S. (12 Wheat.) 460 (1827).

s1 Id. at 469 .

52 The formulation of Rule 801 (d)(2)(E), see supra note 3, preserves the traditional "pendency" and "furtherance" requirements for coconspirator hearsay. The Rule admits coconspirator declarations made "during the course and in furtherance of the conspiracy" as fitting into "the accepted pattern." See FED. R. EvID. 801(d)(2)(E) advisory committee's note. While a charge of conspiracy is not a prerequisite to admissibility, see United States v. Trowery, 542 F.2d 623, 627 (3d Cir. 1976), cert. denied, 429 U.S. 1104 (1977); C. MCCoRMICK, supra note 43, § 267, at 794, the government is required to prove the existence of a conspiracy by a preponderance of the evidence.

See Bourjaily v. United States, 55 U.S.L.W. 4962, 4964-65 (U.S. June 23, 1987).

${ }^{33}$ FED. R. EvID. 801(d)(2)(E) advisory committee's note.

34 See Koninklijke Luchtvaart Maatschappij N.V. KLM Royal Dutch Airlines Holland v. Tuller, 292 F.2d 775, 784 (D.C. Cir.), cert. denied, 368 U.S. 921 (1961); New Jersey Supreme Court, CommitTeE on EvidenCe Report 165-67 (1963) [hereinafter NEw JERSEY REPORT].

ss The best argument for applying the agency rationale to the statements of cocon- 
scarcely complain if the court refuses to take seriously his allegation that his extra-judicial statements are [not] worthy of credence, ${ }^{, 56}$ or who "can hardly be heard to object . . . that he had no opportunity to cross-examine himself," $"$ and unlike an agent, whose interests may in some cases be aligned with those of her principal, the "hearsay statements of alleged co-conspirators are perhaps the most suspect of all."

It has been said that evidence received under Rules 803 and 804 as exceptions to the rule against hearsay is admissible because it possesses some guarantee of reliability. ${ }^{5 \theta}$ No assurance of reliability is demanded of admissions, however. ${ }^{80}$ Yet the rationale that justifies admitting the statements of a party-opponent-that a party cannot complain that she is not worthy of belief or that she had no opportunity to cross-examine herself-simply cannot be logically extended to the statements of a nonparty. ${ }^{61}$ There is even less reason to extend this doctrine to the statements of coconspirators, who may have positive incentive to lie in order to strike a deal or exculpate themselves. ${ }^{62}$ Certainly, a defendant may well assert that a coconspirator is unworthy of credence and can rightfully demand to cross-examine her accuser. The present rule, on the basis of an ancient and irrational legal fiction, ${ }^{63}$ denies the defendant this opportunity while dispensing with basic guarantees of trustworthiness, such as the requirement that a hearsay declarant have personal knowledge of the facts underlying her statement.

Personal knowledge is "[o]ne of the earliest and most pervasive manifestations" of the common law's "insistence upon the most reliable

spirators may be made in cases of so-called "chain" conspiracy, where the declarant gave actual instructions to those below ( $A$ instructed $B, B$ instructed $C$, and so on) and was a central figure in the conspiracy. In the case of "wheel" conspiracy, however, where there is communication between the "hub" and the coconspirators, or "spokes," but not between the "spokes" themselves ( $A$ instructed $B, A$ instructed $C$, and so on), there is in reality more than one conspiracy. See Model Penal Code \$5.03, at 120 (Tent. Draft No. 10, 1960). Indeed, it may be in the interest of the declarant to lie. See Levie, supra note 6 , at 1165 .

so Morgan, supra note 46 , at 461.

87 Id.

sB New Jersey Report, supra note 54, at 167; see also Comment, The Hearsay Exception for Co-Conspirators' Declarations, 25 U. CHI. L. REv. 530, 541 (1958) (stating that coconspirators' declarations are unreliable and easy to fabricate).

${ }^{80}$ See United States v. Ammar, 714 F.2d 238, 255 (3d Cir.), cert. denied, 464 U.S. 936 (1983); FED. R. EvID. 803 advisory committee's note ("The present rule proceeds upon the theory that under appropriate circumstances a hearsay statement may possess circumstantial guarantees of trustworthiness sufficient to justify nonproduction of the declarant . . ."); C. MCCormICK, supra note 43, § 262, at 775; $5 \mathrm{~J}$. WIGMORE, supra note $43, \S \S 1420,1422$, at 251-54.

60 See supra note 9 and accompanying text.

61 See supra notes $25 \& 46$ and accompanying text.

62 See infra notes 65-66 and accompanying text.

63 See supra note 53 and accompanying text. 
sources of information." While reliability is arguably not a concern where a party herself is the declarant, it is a serious problem in the context of coconspirator declarations:

Conspirators' declarations are good to prove that some conspiracy exists but less trustworthy to show its aims and membership. The conspirator's interest is likely to lie in misleading the listener into believing the conspiracy stronger with more members (and different members) and other aims than in fact it has. It is no victory for common sense to make a belief that criminals are notorious for their veracity the basis for law. ${ }^{65}$

Justice Marshall put it differently, though no less eloquently, when he added: "The unreliability of co-conspirator declarations as trial evidence is not merely a product of the duplicity with which criminals often conduct their business. It also stems from the ambiguities that so often appear in all casual conversations, not just those of outlaws." ${ }^{\text {"B6 }}$

Federal Rule of Evidence 801(d)(2)(E) incorporates pendency and furtherance requirements, which, by requiring that a statement be made in the course and in furtherance of the conspiracy, ${ }^{67}$ are said to ensure the reliability of coconspirator hearsay admitted as substantive evidence. $^{68}$ These requirements alone, however, cannot guarantee trustworthiness. A brief illustration may suffice. Imagine four men involved in an ongoing conspiracy to rob banks: two, $A$ and $B$, carry out the actual holdups; one, $C$, drives the getaway car; and a fourth, $D$, awaits the others at a safe location. At the scene of their latest crime, coconspirator $C$, in the car, hears gunshots and sees $A$ run from the bank. In a panic $C$ drives away. He subsequently learns that $B$ and a teller died

64 C. McCormICK, supra note 43, $\S 10$, at 23; accord FED. R. Evid. 602 advisory committee's note.

Bs Levie, supra note 6, at 1165-66.

B United States v. Inadi, 106 S. Ct. 1121, 1131-32 (1986) (Marshall, J., dissenting). It should be noted that personal knowledge of the declarant is one of the "indicia of reliability" cited in Dutton v. Evans, 400 U.S. 74, 88-89 (1970), a case that dealt with the requirements of the confrontation clause of the sixth amendment. Inadi, another confrontation clause case, did not resolve the question of whether the confrontation clause always requires personal knowledge, nor did it deal with what the sixth amendment requires of coconspirator declarations in terms of reliability. See Inadi, 106 S. C.t. at 1124 n.3 ; id. at 1129 n.1 (Marshall, J., dissenting). Recently, the Court has concluded that "independent indicia of reliability" are indeed not required by the Constitution. See Bourjaily v. United States, 55 U.S.L.W. 4962,4965 (U.S. June 23, 1987). This Comment, however, is concerned only with the Federal Rules of Evidence, and the complexities of the confrontation clause are beyond its scope.

o7 See supra note 52.

${ }^{68}$ See Mueller, supra note 48 , at 356. 
in the gunfire. $C$ tells $D$, in an effort to persuade $D$ that they should flee the state and ply their nefarious trade elsewhere, " $A$ killed a man." At $A$ 's trial for bank robbery, or perhaps felony murder, $D$ 's testimony as to $C$ 's statement would be fully admissible under the Ammar rule against $A$ as a coconspirator declaration, even though $C \operatorname{did}$ not see the shooting, because the pendency and furtherance requirements are satisfied. ${ }^{69}$

The example can be further complicated. Suppose $D$ is apprehended and is about to be tried. The ambitious prosecutor would rather get a capital murder conviction ${ }^{70}$ and offers $D$ the opportunity to plead to a lesser charge in return for his testimony against $A$. Even assuming no bad faith on the parts of those involved ${ }^{71}$ - both $C$ and $D$ may sincerely believe that it was in fact $A$ who pulled the trigger-the testimony of $D$ as to $C$ 's statement, " $A$ killed a man," is admissible under Ammar against $A$ even though neither $C$ nor $D$ witnessed the shooting. Because $C$ 's statement is admissible as substantive evidence against $A$ under Rule $801(\mathrm{~d})(2)(\mathrm{E})$, it is possible that $A$ might be convicted of a capital offense on the basis of a statement that was not based on the declarant's firsthand knowledge of the facts. $A$ is thus put in the unenviable position of being forced either to take the stand, where to all appearances he will be attempting to heap the blame onto his dead friend $B$, or to rely on cross-examination to undo the prejudicial effect

${ }^{89}$ A conspiracy does not end merely because one of the conspirators has been arrested, see, e.g., Ammar, 714 F.2d at 253 (" $[t]$ he arrest of some of the conspirators, even its principal member, does not necessarily terminate the conspiracy." (citation omitted)); United States v. Killian, 639 F.2d 206, 209 (5th Gir. Unit A Mar.), cert. denied, 451 U.S. 1021 (1981), especially where, as here, the conspiracy continues to be viable. Moreover, a conspiracy is presumed to continue until defendants make an affirmative showing to the contrary. See United States v. Hamilton, 689 F.2d 1262, 1268-69 (6th Cir. 1982), cert. denied, 459 U.S. 1117 (1983). C's statement to $D$ is in furtherance of their joint venture because it is part of a plan to carry on as before in another jurisdiction. Statements are in furtherance of a conspiracy when made to inform a conspirator of its "current status," see, e.g., Ammar, 714 F.2d at 252, to reassure or maintain trust, see, e.g., id., or to make plans, see, e.g., Hamilton, 689 F.2d at 1269. Although these conclusions may of course be disputed, the reader should assume for the sake of argument that a court could reasonably find the pendency and furtherance requirements satisfied.

${ }^{70}$ The imposition of the death penalty for felony murder, in the absence of major participation in the underlying felony coupled with reckless indifference to human life, see Tison v. Arizona, 55 U.S.L.W. 4496, 4502 (U.S. Apr. 21, 1987), where the defendant "neither took life, attempted to take life, nor intended to take life," is inconsistent with the eighth and fourteenth amendments. See Enmund v. Florida, 458 U.S. 782, 787-88 (1982). Thus, $A$ could not be sentenced to death if he did not pull the trigger, unless there were a finding that he acted with reckless indifference.

71 There may, of course, be considerable motive for $D$ to lie. See supra notes 6566 and accompanying text. 
of $C$ 's out-of-court declaration. ${ }^{72}$ Requiring that $C$ have personal knowledge of the facts underlying his statement, " $A$ killed a man," would eliminate no trustworthy evidence and would exclude unreliable and highly damaging testimony by one of $A$ 's close associates.

At this point our ambitious prosecutor will claim that in cases of criminal conspiracy there is a special need for the evidence. This is often advanced as the "real" reason for admitting coconspirator hearsay. ${ }^{73}$ It is true that a conspiracy is a shadowy beast, not often seen in the daylight, and its existence is difficult to prove. ${ }^{74}$ Yet prosecutorial convenience alone "should not justify departure from the usual order of proof because once evidence is admitted it can never really be stricken."75 The admission of unreliable evidence under this rationale recalls the words of the judges in Sir Walter Raleigh's Case: ${ }^{78}$ "[I]t might be a mean to cover many with treasons, and might be prejudicial to the King."

\section{B. The Testimonial Anomalies}

Perhaps the most curious effect of the doctrine that allows the substantive use of vicarious admissions not based on the declarant's personal knowledge is that it leads to two distinct anomalies. First, while the declarant could not testify to the content of her statement in court because of her lack of personal knowledge of the subject matter, her extrajudicial utterance is fully admissible. ${ }^{78}$ For example, in Mahlandt, ${ }^{79}$ although Mr. Poos' out-of-court statement, "Sophie had bit a

72 It may be that subsequent explanation is an adequate safeguard against the prejudicial effect of an admission. See C. MCCoRMICK, supra note $43, \S 263$, at 779 n.14. At best this is a highly controversial view; at worst, it is an "unmitigated fiction." Krulewitch v. United States, 336 U.S. 440, 453 (1949) (Jackson, J., concurring).

${ }^{73}$ See 4 J. WEINSTEIN \& M. BERGER, supra note 26, ๆ $801(\mathrm{~d})(2)(\mathrm{E})[01]$, at 801 233; Levie, supra note 6, at 1166.

74 See Levie, supra note 6, at 1166.

78 Id. at 1178 .

761 D. Jardine, Criminal Trials $389-520$ (1832).

77 Id. at 427.

${ }^{78}$ See Falknor, supra note 46 , at 860 . Falknor illustrates this problem with, oddly enough, a dog-bite case:

It certainly seems anomalous that where the question is whether the defendant's dog jumped on a woman, defendant's out-of-court statement that such had occurred (although concededly the defendant was not present at the time) may be shown (for substantive use) when it is perfectly clear that the defendant would not be permitted to testify that the dog did not jump on the woman.

Id. (citing Janus v. Akstin, 91 N.H. 373, 20 A.2d 552 (1941)); see also Bein, supra note 21 , at $401 \mathrm{n} .58$ (doctrine admitting agents' statements not based on personal knowledge creates an anomaly).

${ }^{79}$ Mahlandt $v$. Wild Canid Survival $\mathcal{E}$ Research Center, Inc., 588 F.2d 626 
child that day," employer, defendant Wild Canid, ${ }^{81} \mathrm{Mr}$. Poos, because he did not see the attack, would have been prohibited from actually testifying that Sophie had attacked Daniel Mahlandt. ${ }^{82}$ And in our bank robbery hypothetical, $C$ would not be permitted to testify that $A$ did-or did not, for that matter-shoot the teller, ${ }^{83}$ while his out-of-court statement on that subject would be admissible under Ammar. ${ }^{84}$

It is not difficult to see the illogic inherent in this result. Reason teaches that a "live" witness is to be preferred to a "hearsay" witness, ${ }^{85}$ yet under the Ammar court's interpretation of Rule 801(d)(2), hearsay testimony is preferred to live testimony when that hearsay is at its most unreliable. It seems incredible that the drafters of the Rules could have intended such a result, although it has been said that the value of coconspirator hearsay, at least, lies in its "independent evidentiary significance" as a sort of "snapshot" of a situation that cannot be replicated at trial. ${ }^{86}$ If there is any "independent evidentiary significance" to coconspirators' statements and other vicarious admissions not based on personal knowledge, it must relate to the state of mind or belief of the declarant, and to admit this as substantive evidence against another makes little sense. The uninformed speculation of a criminal is simply not reliable proof of objective fact.

The second anomaly created by the admission of coconspirator hearsay not based on the declarant's personal knowledge may be termed a "hearsay within hearsay" problem. ${ }^{87}$ A coconspirator declaration that is not based on firsthand knowledge must be based upon either speculation or gossip. ${ }^{88}$ In the case of "speculation-based" statements, the danger is from "implicit" hearsay within hearsay. Let us return to our bank robbery hypothetical to illustrate. If $D$ testifies, as is permitted under Ammar, to $C$ 's statement, " $A$ killed a man," the wit-

(8th Cir. 1978).

80 Id. at 629.

81 See id. at 630 .

82 See FED. R. Evid. 602 (requiring witnesses to have personal knowledge of the matters to which they testify).

ss See id.

s4 See Ammar, 714 F.2d at 254.

${ }^{85}$ See Inadi, 106 S. Ct. at 1126 ("When two versions of the same evidence are available, longstanding principles of the law of hearsay . . f favor the better evidence." (citation omitted)).

${ }^{86}$ See id. at 1126-27.

${ }^{87}$ The problem is not confined to coconspirator hearsay, however. All statements not founded on firsthand knowledge carry with them a certain risk of "smuggled-in" hearsay.

${ }^{88}$ See 4 J. Weinstein \& M. Berger, supra note 26, II 801(d)(2)(C)[01], at 801216 to -217 . 
ness testifies not only to one extrajudicial statement admitted for its truth, ${ }^{89}$ but to two. The second piece of hearsay is $C$ 's opinion, formed upon seeing $A$ flee the bank in the wake of gunfire. $C$ has in effect read into $A$ 's actions an assertion-or in this case, an admission of guilt. ${ }^{90}$ $C$ 's assumption, based upon facts that were translated by him into an assertion, and admitted to prove that $A$ killed the teller, is fraught with the usual hearsay dangers: ${ }^{91}$ the risks of insincerity and faulty perception, memory, and narration. ${ }^{\mathbf{2}}$

Under the Federal Rules of Evidence, of course, this second or implicit assertion is "not hearsay" because the "declarant," $A$, is a coconspirator as well. ${ }^{93}$ Furthermore, "nothing is an assertion," under the Rules, "unless intended to be one." thus be as admissible under Ammar as the first, explicit statement, " $A$ killed a man." Mere technical admissibility, however, cannot overcome the fact that the reliability problems of coconspirator hearsay in general are compounded when that hearsay is not based on the declarant's firsthand knowledge of the underlying facts.

The significance of this "hearsay within hearsay" problem is perhaps clearer in the case of "gossip-based" hearsay. If an out-of-court statement is founded on gossip, only the fact that the declarant has been cryptic about the source of her information may save the statement

89 The Federal Rules of Evidence define "hearsay" as "a statement, other than one made by the declarant while testifying at the trial or hearing, offered in evidence to prove the truth of the matter asserted." FED. R. EviD. 801(c). If not for the exclusion provided in Rule 801 (d)(2), admissions would of course qualify as hearsay under this definition.

${ }^{80}$ Cf. Ammar, 714 F.2d at 250 (coconspirator described an unidentified man as defendant's "friend," having seen the two together previously, although this characterization was not based on the coconspirator's personal knowledge).

${ }^{21}$ See 4 J. Weinstein \& M. Berger, supra note 26, f 801(d)(2)(C)[01], at 801216 to -217 .

${ }_{92}$ See FED. R. Evid., art. VIII, advisory committee's note.

93 See FED. R. Evid. 805 ("Hearsay included within hearsay is not excluded under the hearsay rule if each part of the combined statements conforms with an exception to the hearsay rule provided in these rules.") and 801(d)(2)(E) (excluding coconspirator statements from the definition of hearsay given in Rule 801(c)).

94 FED. R. Evid. 801(a) advisory committee's note. This was not always so. At common law, an assertion implied from conduct was in fact hearsay, even if the conduct was not so intended. See Wright v. Tatham, 7 Eng. Rep. 559, 584 (H.L. 1838) (Vaughan, J.) ("Acts performed by strangers, expressive not merely of opinion, but of the strongest conviction ... even such acts as these the law will not allow to be presented to the minds of jurymen as evidence. They are merely opinions expressed in different language, in the language of conduct, instead of the language of words. .. . [A]s the opinions of strangers, they bear the general insufficiency and infirmity of hearsay evidence, without any claim to the privilege which in some peculiar subjects of inquiry is extended to that class of proof."); see also United States v. Zenni, 492 F. Supp. 464, 466-67 (E.D. Ky. 1980) ("[The holding of Wright] was the prevailing common law view."). 
from exclusion under Rule 805 as impermissible hearsay within hearsay. ${ }^{95}$ For example, in Mahlandt, the person who found the injured Daniel Mahlandt with Sophie was Kenneth Poos' seventeen-year-old son Clarke, ${ }^{96}$ and it is probable that it was Clarke who told his father that Sophie bit young Daniel. Had Mr. Poos told his employer, "My son told me that Sophie had bit a child that day," his statement would have been inadmissible hearsay within hearsay under Rule 805 for the simple reason that there is no father-son hearsay exception. ${ }^{97}$ The result is that ambiguous utterances receive preferential treatment under the Rules, and again, it is difficult to believe that the drafters intended to create such an anomaly.

\section{CONCLUSION}

A personal knowledge requirement is necessary to ensure the reliability of coconspirator statements admitted under Federal Rule of Evidence $801(d)(2)(E)$. Indeed, one noted authority believes that a personal knowledge requirement for Rule $801(\mathrm{~d})(2)$ is mandated by the rationales of Rules 403 and $805 . .^{88}$ This view, however, has thus far been given short shrift by the courts that have considered it; ${ }^{.9}$ undoubtedly most feel constrained by history and the Advisory Committee. ${ }^{\mathbf{1 0 0}}$ For this reason, the Advisory Committee's Note to Federal Rule of Evi-

${ }^{96}$ See supra note 93 and accompanying text.

${ }^{98}$ See Mahlandt, 588 F.2d at 628.

97 See supra note 93 and accompanying text.

98 See 4 J. WEINSTEIN \& M. BERGER, supra note 26 , ๆ 801(d)(2)(C)[01], at 801217 to -218 , If 801 (d)(2)(D)[01], at 801-226 to -227 , and If 801 (d)(2)(E)[01], at 801257 to -258 .

Rule 403 permits the exclusion of unfairly prejudicial evidence. See FED. R. EvID. 403. Rule 805 allows the admission of hearsay within hearsay if each part of the statement fits into a hearsay exception. See FED. R. EvrD. 805; supra notes 87-97 and accompanying text. As Judge Weinstein notes in his treatise, read literally, Rule 805 will not exclude an admission as hearsay because party admissions are termed "not hearsay" in Rule 801(d)(2). See 4 J. WEINSTEIN \& M. BERGER, supra note 26, II 801(d)(2)(C)[01], at 801-217.

${ }_{99}$ See, e.g., Union Mut. Life Ins. Co. v. Chrysler Corp., 793 F.2d 1, 9 (1st Cir. 1986); Mahlandt v. Wild Canid Survival \& Research Center, Inc., 588 F.2d 626, 63031 (8th Cir. 1978). Although it is not altogether clear, the Mahlandt court seems to say that a statement not based on personal knowledge is opinion testimony rather than hearsay, so Rule 805 , which deals with hearsay, does not apply. This entirely misses Judge Weinstein's point, namely that the philosophy of Rules 805 and 403 dictates that unreliable evidence of this type be excluded. This result of course cannot be reached by a literal reading of Rule 805. See supra note 98. The Union Mutual court, on the other hand, draws a line between the source of information and the conclusions that the declarant draws from that information, and seems to say that hearsay dangers are present only in the first instance. It is difficult to see the logic in this distinction. See supra notes 87-97 and accompanying text.

${ }^{100}$ See supra note 9 and accompanying text. 
dence 801(d)(2) should be redrafted to bring the admissions of coconspirators, which are in the most serious need of an adequate assurance of trustworthiness, under the umbrella of Rule 602's personal knowledge requirement. ${ }^{101}$ Reading such a requirement into Rule 801 (d)(2)(E) would not put reliable evidence of criminal conspiracy beyond prosecutorial reach and would impose no burden not already borne by the government for all other evidence in federal court.

101 One commentator has argued that the federal coconspirator hearsay exception of Rule $801(\mathrm{~d})(2)(\mathrm{E})$ should be amended to require a showing of trustworthiness for statements admitted thereunder. See Mueller, supra note 48, at 388-89; $c f$. Bein, supra note 21, at 451 (urging that Rule $801(\mathrm{~d})(2)(\mathrm{C})$ and (D) be redrafted as an exception to the hearsay rule, incorporating an explicit personal knowledge requirement). Even if the prosecution should not be burdened with the requirement that it make an affirmative showing of trustworthiness, it is difficult to conceive of a persuasive reason to admit coconspirator hearsay shown to be untrustworthy because it was not based on the declarant's personal knowledge. 